\title{
Development a Statistical Relationship between Compressional Wave Velocity and Petrophysical Properties from Logs Data for JERIBE Formation ASMARI Reservoir in FAUQI Oil Field
}

\author{
Qahtan A. Abdul-Aziz and Hassan A. Abdul-Hussein
}

Petroleum Engineering Department, College of Engineering, University of Baghdad, Baghdad, Iraq

\begin{abstract}
The Compressional-wave $(\mathrm{Vp})$ data are useful for reservoir exploration, drilling operations, stimulation, hydraulic fracturing employment, and development plans for a specific reservoir. Due to the different nature and behavior of the influencing parameters, more complex nonlinearity exists for $\mathrm{Vp}$ modeling purposes. In this study, a statistical relationship between compressional wave velocity and petrophysical parameters was developed from wireline log data for Jeribe formation in Fauqi oil field south Est Iraq, which is studied using single and multiple linear regressions. The model concentrated on predicting compressional wave velocity from petrophysical parameters and any pair of shear waves velocity, porosity, density, and fluid saturation in carbonate rocks. A strong linear correlation between P-wave velocity and S-wave velocity and between P-wave velocity and density rock was found. The resulting linear equations can be used to estimate $\mathrm{P}$-wave velocity from the $\mathrm{S}$-wave velocity in the case of both. The results of multiple regression analysis indicated that the density, porosity, water-saturated, and shear wave velocity $\left(\mathrm{V}_{\mathrm{S}}\right)$ are strongly related to $\mathrm{Vp}$.
\end{abstract}

Keywords: Porosity, Water saturation, Multiple regression, compressional wave

Received on 18/04/2021, Accepted on 04/07/2021, published on 30/09/2021

https://doi.org/10.31699/IJCPE.2021.3.1

\section{1- Introduction}

Since carbonate rocks are essential components of the world's oil and gas reservoirs, further research into their physical characteristics is required. When combined with shear wave velocity $(\mathrm{Vs})$, compressional wave velocity becomes a useful parameter for seismic analysis, lithologic identification [1,2], and pore fluid and pore pressure information $[3,4,5]$.

A logical relationship between inputs (well log data) and outputs $(\mathrm{Vp})$ is required for selecting input data. Many factors influence compressional wave velocity; four of the most significant in carbonate rocks are neutron porosity (NPHI) and bulk density (RHOB), s-wave, and pour water. In addition, weathering, alteration zones, bedding planes, and joint properties (filling materials, roughness, water, dip, and strike, and so on) all affect the sound velocity $[6,7,8,9,10,11]$.

Velocity is determined by the ratio of rock moduli to density. The elastic moduli by density term, dependent on rock properties such as fluid saturation and rock texture, produce velocity variations. The theory of elasticity in rocks demonstrates that seismic waves propagate in two mechanisms, each propagating independently [12]. The work of rock moduli over density can estimate the seismic velocities, Vp and Vs., of isotropic rock material.
When the rock is saturated with water, compressional waves move faster than when it is dry or gas-saturated.

Shear waves have the opposite behavior, with shear velocities higher in dry or gas-saturated cases than in water-saturated cases $[13,14]$. At $10 \%$ saturation, the strongest decrease in intensity was observed. The volumetric pressure of the cracks and the sample decreased as the water saturation decreased, owing to water easing crack initiation and propagation [14].

The compressional wave $(\mathrm{Vp})$ can estimate the water absorption characteristic as an objective parameter. However, water absorption, which is an effective rock index, is dependent on the mineralogy and porosity of the rock $[15,16]$.

Several researchers [18, 19, 20, 21, and 22] established empirical correlations to estimate compressional wave velocities. The amount of data collected has a big impact on empirical predictions. Predictions of this kind can also be used for effective planning.

Table 1 shows a range of relationships for predicting compressional waves from petrophysical parameters that have been published. As a result, using Petrophysical properties to predict compressional waves is more accurate, particularly in carbonates rocks. 
Table 1. Previous empirical relationships for compressional wave prediction

\begin{tabular}{|c|c|c|}
\hline Reference & Relationshiof Vp $(\mathrm{km} / \mathrm{sec})$ & year. \\
\hline (Pickett, 1963) & $\mathrm{Vp} / \mathrm{Vs}=1.8$ or $\mathrm{Vp}=1.8 \mathrm{Vs}$ & 1963 \\
\hline Gist et al 1993 & $\mathrm{Vp}=5.45--6.17 \emptyset$ & 1993 \\
\hline Christensen and Stanly & $V p=2.8 \rho-1.5752$ & 2003 \\
\hline Morteza Karam et al. & $V p=0.09 V s+1.95$ & 2012 \\
\hline Siddharth Garia & $V p=2.7037 \rho-2.3668$ & 2019 \\
\hline Siddharth Garia, et,al. & $V p=6.12-0.444 W a$ & 2019 \\
\hline
\end{tabular}

However, there are some studies in existence that use multiple regressions and come up with encouraging results. This research focus is developing a single and multiple regression $\mathrm{Vp}$ prediction in carbonates by utilization of conventional well logs.

This study presents a regression analysis (statistical method) used to create a correlation to predict compressional waves and among effective petrophysical properties in dolomite formation (carbonate reservoirs) using JMP software.

The development of empirical models in which the measurable well $\operatorname{logs}$ can estimate $\mathrm{Vp}$ will also be outlined multiple regression for accurate prediction of $\mathrm{Vp}$ in the investigated reservoir.

\section{2- Material and Methods}

Missan Oilfield is located in southeastern Iraq and close to the Iraq-Iran border. The field consists of three producing oilfields, namely Abu Ghirab, Buzurgan, Fauqi oilfields. Structurally Fauqi oilfield ranges about $30 \mathrm{~km} \times$ $7 \mathrm{~km}$ with two domes in the north and south, respectively; NW-SE long axis anticline has two sets of reservoirs, Tertiary Asmari and Cretaceous Mishrif. Asmari reservoir is divided into three pay zones.A,B,and C. The pay zone, A of Asmari consists of the main dolomite (Jeribe formation). The interval of Jeribe is from depth 2996 to $3044 \mathrm{~m}$; this interval is the area of the present study.

There is no depth on the compressional waves (VP), but the $(\mathrm{VP})$ is affected by the petrophysical properties.

The pay zone B is dolomite intercalated with sandstone, limestone, and thin shale. The pay zone $\mathrm{C}$ is mainly the sandstone, intercalated with a few dolomite, mudstone, and limestone.

The study presents multivariate regression analysis using the JMP software to develop a new correlation to predict compressional waves and among effective petrophysical properties of a productive carbonate (dolomite) section of Southeast Iraq (FAUQI A field JERIBE formation).

The JERIBE Formation is considered one of the important reservoirs in the Misan oilfields.

It will also be discussed how to construct empirical models that use observable well logs to estimate Vp. The relationship between the input data and the outcomes was verified using data analysis.

Logs and core plugs can also calculate sonic wave data, but logs provide more data and a better representation of a reservoir [23].
Because of the complexity of the relationship between (Vp) values and all rock and fluid properties, only the most essential and observable rock and fluid properties (as determined by well logging data) were chosen as the model's key input parameters.

As a result, the parameters chosen should have a significant impact on $\mathrm{Vp}$.

To determine which variables have the most significant impact on $(\mathrm{Vp})$, as well as to compare the relationship between compressional wave velocity and other parameters and petrophysical logs (Vs., NPHI, RHOB, SW), it was discovered that there is a close relationship between compressional and shear wave velocity, especially in carbonate rocks.

\section{3- Calculations and Analysis}

To model the output function, a collection of observations from the reservoir, such as well logs or core measurements, can be linked to the regression analysis result. Simple regression analysis or a multiple regression analysis may be used to accomplish this. The relationship between two variables is often modeled using simple regression analysis.

On the other hand, multiple regression analysis uses more than one predictor variable and can be more reliable when analyzing p-wave data [24]. Table (2) represents $\log$ data of physical rock properties and elastic waves (Pand $\mathrm{S}$-waves) velocity for Jeribe formation.

The data in table 2 is the sample data used in the program (JMP) software to obtain the relationships between (VP) and the physical properties.

\subsection{Single Linear Regression Analysis}

It can be seen in many engineering problems that specific data varies in an ascending or descending pattern. Many studies have shown, for example, that as Vp rises, the number of rock samples rises as well.

Therefore, it is worthwhile to investigate whether there is a link between -p-wave velocity and petrophysical parameters when estimating carbonate rocks using single linear regression.

\section{a. Relation between P-Wave And S-Wave Velocity}

The compressional wave velocity is linearly related to the shear wave velocity as shown in Fig. 2 the high regression $\mathrm{R}^{2}=0.946$. The scatter of even the mean values around the regression lines is due to complex depositional environments and digenetic processes. Reveals a strong correlation between the two velocities which enables estimation of one velocity having another one; the equation defines this relationship shown below:

$V p=2.122 V s-1.195$ 
b. Relation between P-Wave Velocity and Porosity

A similar trend is presented between compressional wave velocity $(\mathrm{Vp})$ and porosity $(\varnothing)$, plotted in Fig. 3 The p-wave velocity is declining as the porosity decreases.

An important point can be concluded from this figure there is a scattering around the curve which can be attributed to the heterogeneity of carbonate in which the void proportions and pore size distributions within the rock fabric are complex; the relationship between $\mathrm{p}$-wave and porosity gives $\mathrm{R}^{2}=0.759$, and equations of the relation are;

$V p=6.947-0.1542 N P H I$

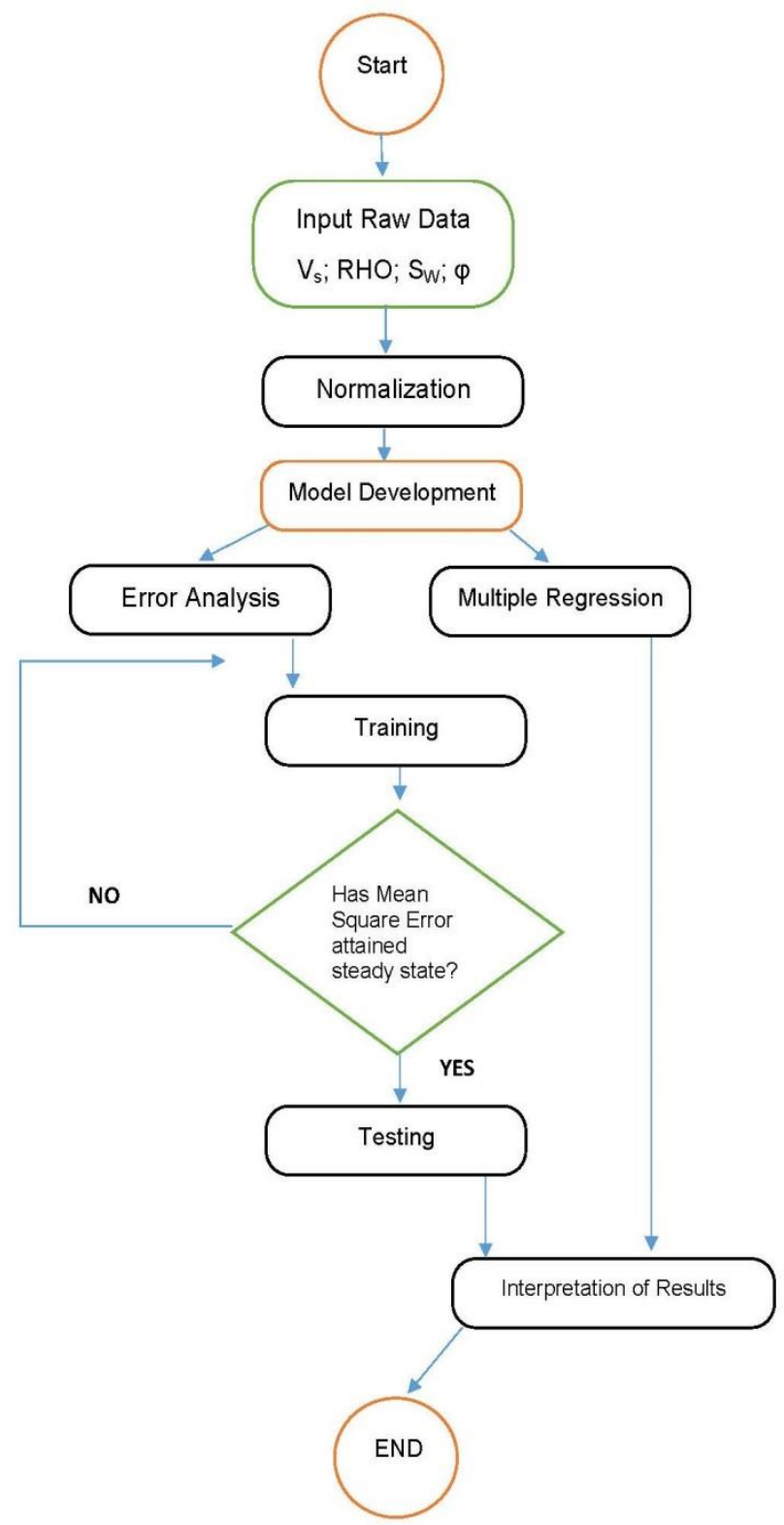

Fig. 1. Flowchart of the computer software to estimate Vp

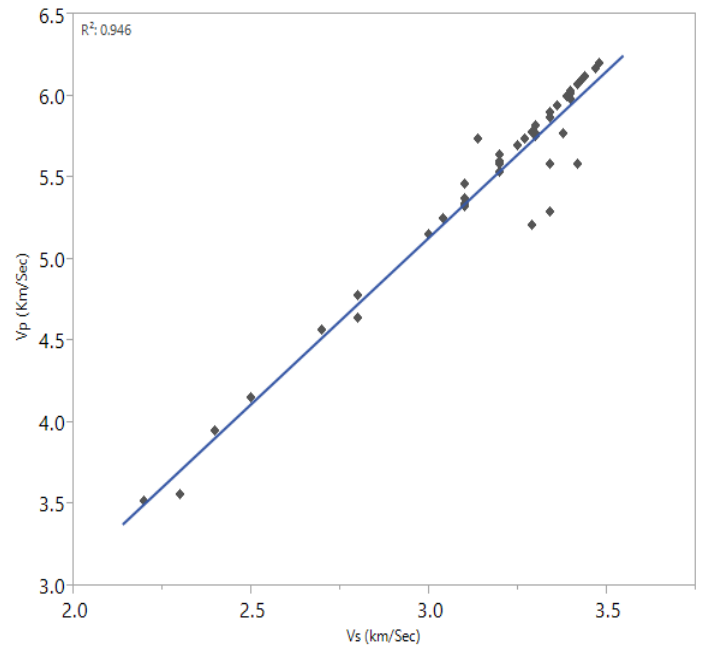

Fig. 2. Compressional wave velocity versus shear wave

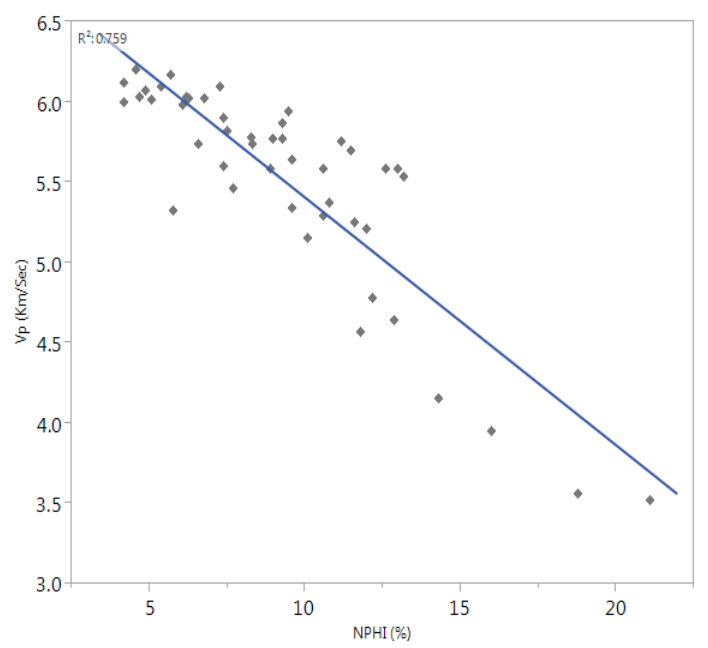

Fig. 3. Compressional wave velocity versus NPHI

c. Relation Between The P-Wave Velocity and Bulk Density

The relationships between the $\mathrm{P}$-wave velocity and rock density have been extensively investigated.

P-wave velocity increases linearly with a bulk density, as shown in Fig. 4.

The results revealed that there is scattering around the bulk density -velocity curves.

This can be attributed to the heterogeneity of carbonates formation, mixed with dolomite intercalated with argillaceous dolomite.

Good relation between p- wave velocity and bulk density with R2 $=0.833$ According to Equation (3) of the relation is;

$V p=4.284 \rho-6.22$ 
Table 2. Results of elastic waves (p-and s-wave velocity) with physical properties for jeribe formation

\begin{tabular}{|c|c|c|c|c|c|}
\hline depth $\mathrm{M}$ & $\begin{array}{l}\mathrm{vp} \\
\mathrm{km} / \mathrm{sec}\end{array}$ & $\begin{array}{l}\text { Vs } \\
\mathrm{km} / \mathrm{sec}\end{array}$ & $\begin{array}{l}\text { Density } \\
\mathrm{gm} / \mathrm{cc}\end{array}$ & NPHI\% & Sw\% \\
\hline 2996 & 5.25 & 3.04 & 2.65 & 0.3 & 56 \\
\hline 2297 & 5.25 & 3.04 & 2.6 & 11.6 & 42 \\
\hline 2998 & 5.89 & 3.34 & 2.76 & 10.6 & 68 \\
\hline 2999 & 5.88 & 3.33 & 2.78 & 10.6 & 82 \\
\hline 3000 & 5.97 & 3.37 & 2.77 & 9 & 92 \\
\hline 3001 & 5.9 & 3.34 & 2.82 & 7.4 & 100 \\
\hline 3002 & 6.07 & 3.42 & 2.87 & 4.9 & 100 \\
\hline 3003 & 6.12 & 3.44 & 2.85 & 4.2 & 100 \\
\hline 3004 & 6.01 & 3.39 & 2.85 & 5.1 & 100 \\
\hline 3005 & 6.2 & 3.48 & 2.85 & 4.6 & 100 \\
\hline 3006 & 6.09 & 3.43 & 2.81 & 5.4 & 100 \\
\hline 3007 & 5.74 & 3.27 & 2.83 & 6.6 & 100 \\
\hline 3008 & 5.74 & 3.34 & 2.74 & 12.7 & 85 \\
\hline 3009 & 5.7 & 3.25 & 2.77 & 11.5 & 67 \\
\hline 3010 & 5.81 & 3.29 & 2.73 & 12 & 65 \\
\hline 3011 & 6.09 & 3.43 & 2.84 & 7.3 & 100 \\
\hline 3012 & 5.87 & 3.34 & 2.84 & 9.3 & 94 \\
\hline 3013 & 5.78 & 3.29 & 2.84 & 8.3 & 56 \\
\hline 3014 & 6.17 & 3.47 & 2.83 & 5.7 & 100 \\
\hline 3015 & 6.08 & 3.42 & 2.79 & 8.9 & 56 \\
\hline 3016 & 6.03 & 3.4 & 2.85 & 4.7 & 100 \\
\hline 3017 & 6.06 & 2.41 & 2.92 & 1.3 & 100 \\
\hline 3018 & 6 & 3.39 & 2.86 & 4.2 & 100 \\
\hline 3019 & 6.02 & 3.4 & 2.82 & 6.8 & 100 \\
\hline 3020 & 6.02 & 3.4 & 2.83 & 6.3 & 100 \\
\hline 3021 & 5.94 & 3.36 & 2.79 & 9.5 & 100 \\
\hline 3022 & 6.03 & 3.4 & 2.83 & 6.2 & 100 \\
\hline 3023 & 5.75 & 3.27 & 2.76 & 11.2 & 65 \\
\hline 3024 & 5.15 & 2.99 & 2.64 & 18.1 & 45 \\
\hline 3025 & 5.34 & 3.08 & 2.65 & 9.6 & 45 \\
\hline 3026 & 4.64 & 2.75 & 1.95 & 12.9 & 19 \\
\hline 3027 & 3.95 & 2.43 & 2.3 & 16 & 22 \\
\hline 3028 & 5.32 & 3.07 & 2.97 & 5.8 & 64 \\
\hline 3029 & 5.6 & 3.2 & 2.81 & 7.4 & 67 \\
\hline 3030 & 5.64 & 3.22 & 2.73 & 9.6 & 82 \\
\hline 3031 & 3.56 & 2.25 & 1.71 & 18.8 & 20 \\
\hline 3032 & 4.78 & 2.82 & 2.54 & 12.2 & 32 \\
\hline 3033 & 5.37 & 3.09 & 2.65 & 10.8 & 71 \\
\hline 3034 & 4.15 & 2.52 & 2.37 & 14.3 & 34 \\
\hline 3035 & 5.82 & 3.3 & 2.79 & 7.5 & 68 \\
\hline 3036 & 5.58 & 3.19 & 2.7 & 12.6 & 74 \\
\hline 3037 & 5.53 & 3.17 & 2.7 & 13.2 & 45 \\
\hline 3038 & 5.58 & 3.19 & 2.86 & 13 & 54 \\
\hline 3039 & 5.98 & 3.38 & 2.82 & 6.1 & 73 \\
\hline 3040 & 5.77 & 3.28 & 2.77 & 9.3 & 78 \\
\hline 3041 & 5.46 & 3.13 & 2.75 & 7.7 & 41 \\
\hline 3042 & 5.53 & 3.17 & 2.8 & 4.2 & 43 \\
\hline 3043 & 4.57 & 2.72 & 2.56 & 11.8 & 37 \\
\hline 3044 & 3.52 & 2.23 & 2.38 & 21.1 & 33 \\
\hline
\end{tabular}

d. Relation between P-Wave Velocity and Water Saturation

The Compressional wave ( $\mathrm{Vp})$ of rocks is influenced when exposed to fluids. The plot below showing in the relation between $\mathrm{p}$ - wave velocity and water saturation values figure. Five, the water saturation increases, and pwave velocity increase with $\mathrm{R}^{2}=0.703$ for dolomite.

According to equation (4), p-wave velocity increase linearly with increasing water saturation. The equation of the relation is:

$V p=4.063+0.02043 * S W$

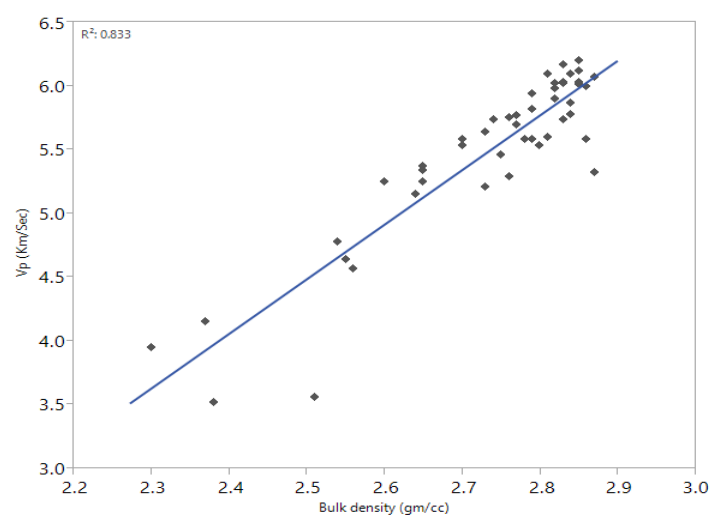

Fig. 4. Compressional wave velocity versus Bulk density

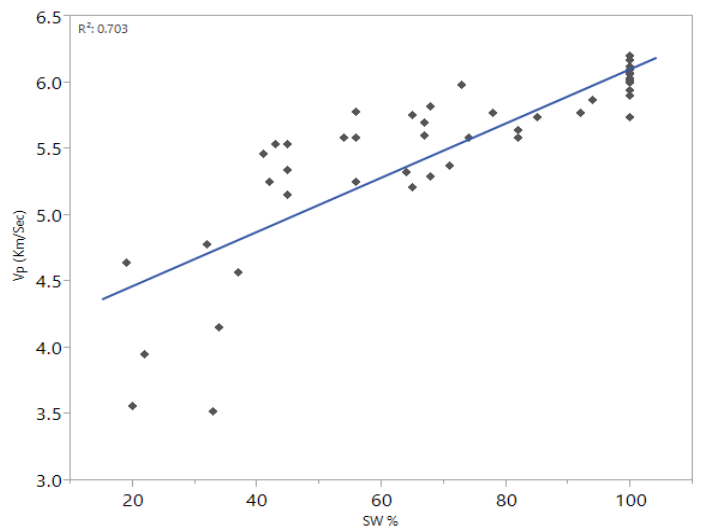

Fig. 5. Compressional wave velocity versus water saturation

e. Comparison Between New Correlations with The Previous Empirical Correlations

In this section, the developed correlations have been compared with some previous correlations in Table. 1. The reason is to check whether this study has improved the literature. Table $\mathbf{1}$ for validation purposes as shown in Fig. 6

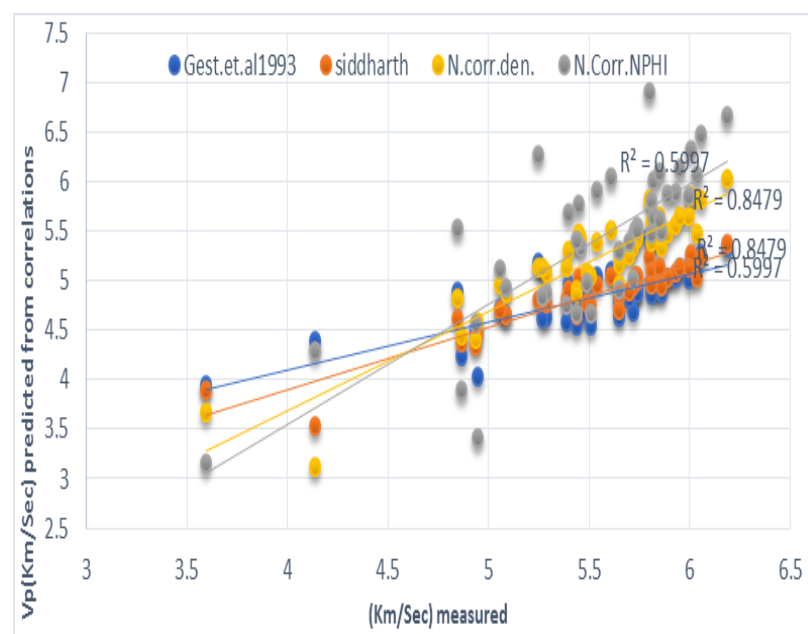

Fig. 6. Comparison between Equations $(2,3)$ and other empirical relations to predict $\mathrm{Vp}$. for dolomite rock formation from log data 


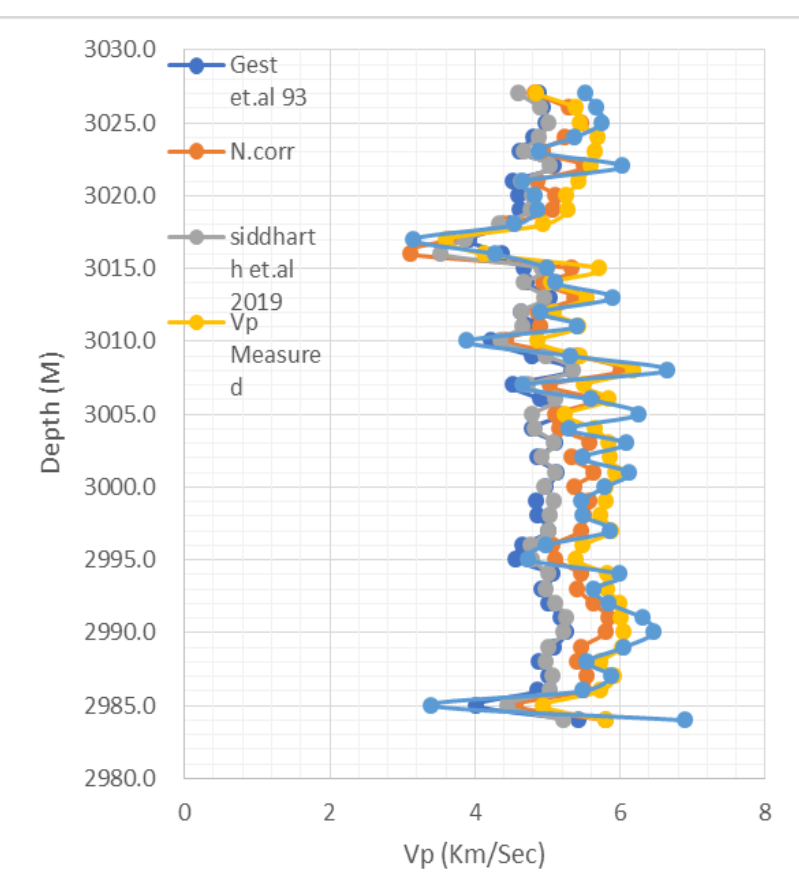

Fig. 7. Measured and predicted Vp using Multivariate Regression. (Eq. 2,3) and other empirical relations

\subsection{Multiple Regressions}

Instead of equations (1, 2, 3, and 4), density (RHOB) and $\mathrm{S}$-wave velocity vs. were used to add to the Vp model to improve the accuracy of the regression (prediction).

The predictive capability of multiple regressions is greatly improved when different variables are used to predict the $\mathrm{P}$-wave velocity. Multiple variables are used to obtain a more accurate prediction of a variable.

Using NPHI (the calculation of neutron porosity), RHOB (the bulk density), and vs. (shear wave velocity) as separate variables, this program uses multiple regression to estimate compressional wave velocity in JMP.

It would help if you started by investigating the relation between compression wave velocity and the parameters you will be controlling (NPHI, RHOB, Sw, and Vs), then look for coefficients (a, b, c, d, e, and $\mathrm{f}$ ) in the equation above to discover that:

$V p=a+b * V S+c * N P H I+d * R H O B+e * S W$

NPHI is neutron porosity expressed as a fraction, RHOB is bulk density in $\mathrm{gm} / \mathrm{cc}, \mathrm{Vp}$ is compressional wave velocity in $\mathrm{km} / \mathrm{s}$, and Vs. is shear wave velocity in $\mathrm{km} / \mathrm{s}$, and $\mathrm{SW}$ is a fraction.

It should be pointed out that using the complete set of input data as parameters in multiple regression models also leads to the use of all of the data available wells. A new model was retimed, and the resulted equation was:

$V p=0.1565+1.6087 * V s-0.0350 * N P H I+0.20409 *$

$R H O B+0.0000403 * S W$
The suggested equation could be as follow:

$V p=a+b * V s+c *(V s+d) 2+e * N P H I+f(N P H I+$ $g) 2+h * R H O B+J * S W$

And the eq. 6 using the JMP software can be written as:

$V p=1.362+1.395 V s-0.647(V s-3.179) 2-0.034 * N P H I+$

$0.002(N P H I-9.348) 2-0.018 * R H O B+0.0014 * S W$

The estimated $\mathrm{Vp}$ using the equation (7) provides a suitable match measured $\mathrm{Vp}$ as shown in Fig. 8 with $\mathrm{R}^{2}$ of about 0.93 , while Fig. 9 presents the computed Vp using equation (7) and log compressional wave velocity from the Real field data versus depth for well 28 in FAUQI oil field.

Fig. 9 shows the continuous profiles of the actual and predicted compressional wave velocities, in which developed equation (7) has shown a reasonably accurate $\mathrm{Vp}$ prediction along the whole section.

Multiple regressions presented a robust correlation to predict compressional wave velocity from well log data. The multiple linear regressions of the presented variables show a strong correlation among $\mathrm{Vp}$ values predicted from well logging data.

All two methods, empirical and multiple regressions were applied log data to predict compressional wave velocity for the carbonate reservoir (dolomite).

The results show that the statistical method performs better than empirical models, which can be used only to obtain an order of magnitude for compressional wave velocity, as shown in Fig. 8, the excellent agreement between filed data and new correlation. For more validation, we compare the new correlation with field data and other mentioned correlations as shown in Fig. 10.

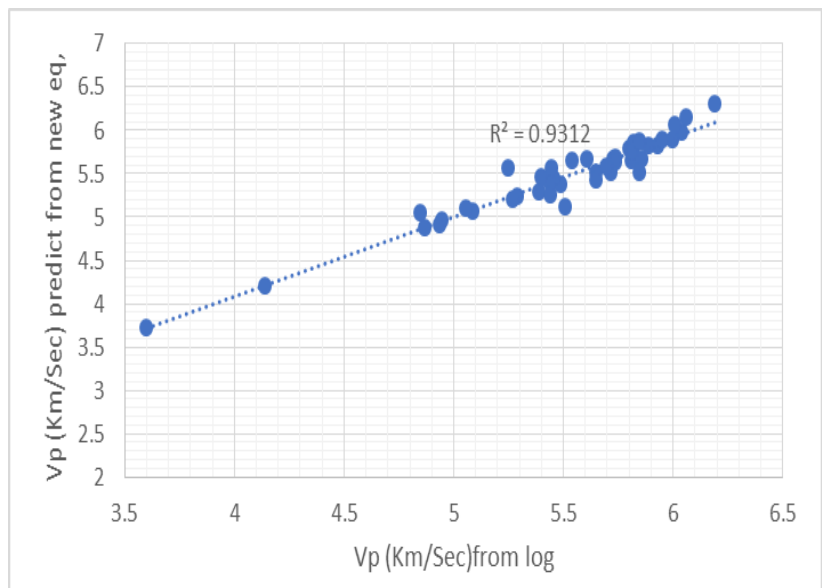

Fig. 8. Plots of predicted Vp using Multivariate regression equation versus measured $\mathrm{Vp}$ from the $\log$ for well FAUQI-27 (Equation 7) 


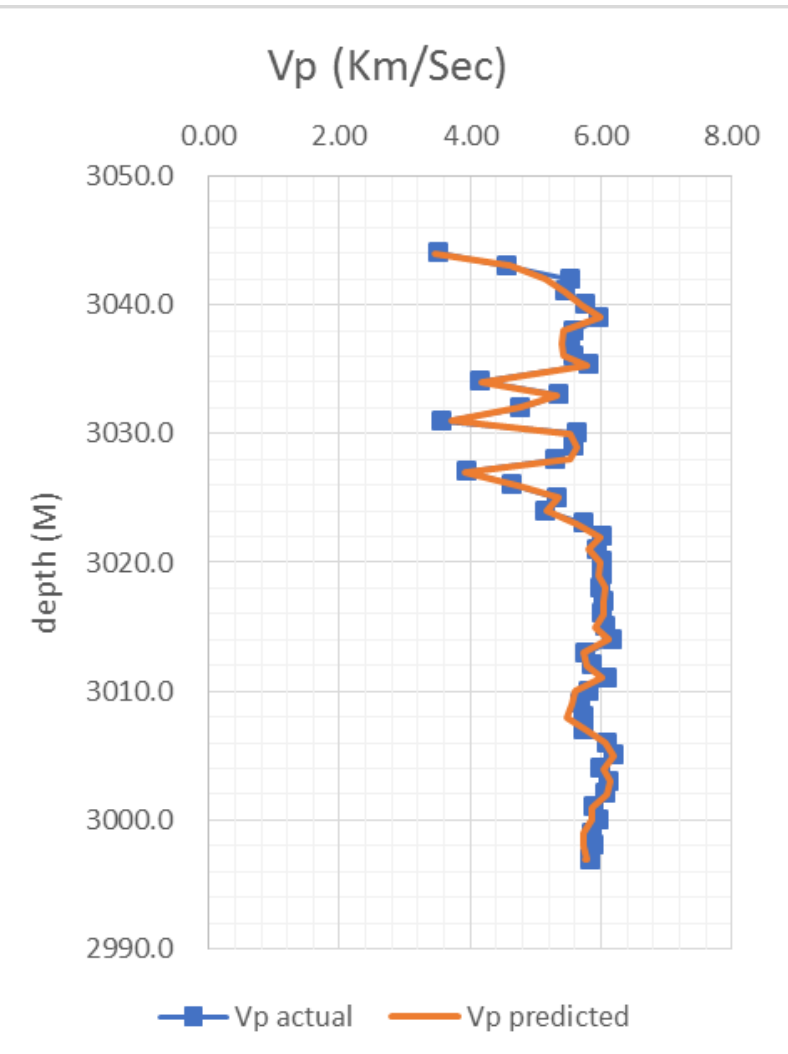

Fig. 9. Measured and predicted $\mathrm{Vp}$ using Multivariate regression equation (Equation 7)

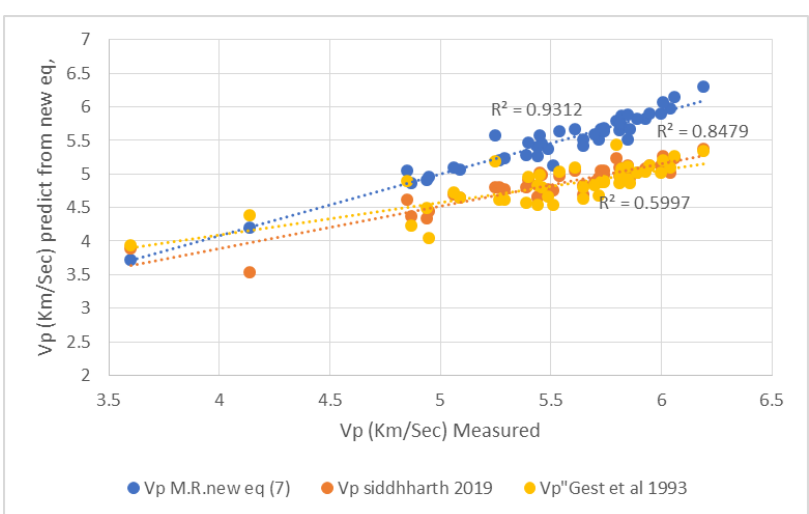

Fig. 10. Comparison between new correlation (Eq. 7) and other correlation with the actual data for FAUQI-27

\subsection{Error Analysis}

To further analyze the errors between calculated p-wave and actual p-wave, the following formula was adopted to calculate the absolute errors: Two criteria were used to evaluate the accuracy of this correlation, eq 7 compared to three correlations. These criteria are [25];

a. The Average Absolute Relative Error, Eq.

$A A R E=\frac{1}{N} \sum_{i=1}^{N}\left[\left|\frac{X \text { measured }(i)-X \text { calculated }(i)}{X \text { measured }(i)}\right|\right] * 100 \%$ b. The Standard Deviation Error is Given By Eq.

$S D=\sqrt{\left(\frac{1}{N-1} \sum_{i-1}^{N}\left[\left|\frac{\text { Xmeasured }(i)-X \text { calculated }(i)}{\text { Xmeaeored }(i)}\right|\right]-A A R E\right)^{2}}$

Fig. 11 shows that the new correlation provides the most accurate results than the other correlations. It gives (0.000451) standard deviation error compared with the other correlations, which give at least double standard deviation error, the new correlation also gives a lower average absolute relative error than the other correlations, as shown in Fig. 12.

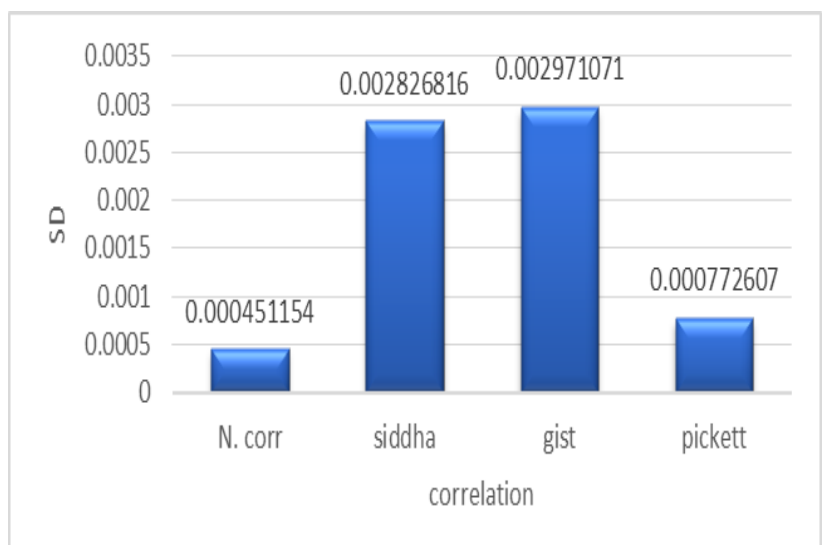

Fig. 11. SD\% for the new and the other three correlations for FAUQI-28

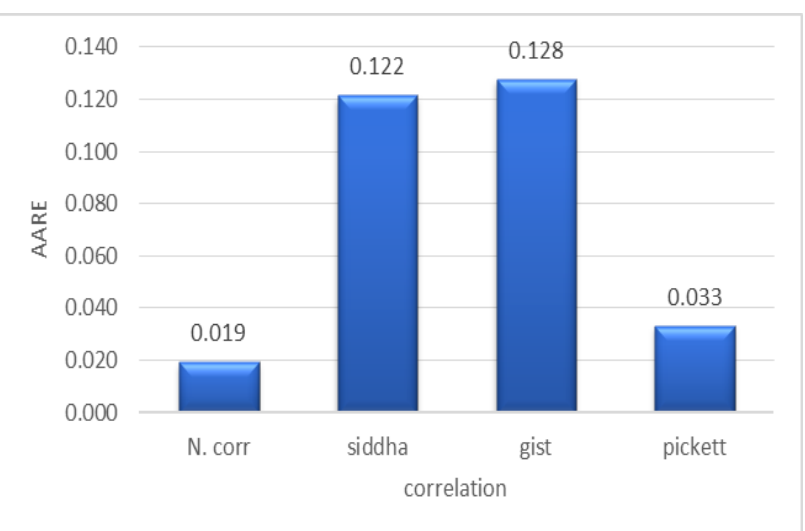

Fig. 12. AARE $\%$ for the new and the other three correlations for FAUQI-28

\section{4- Conclusions}

This study presents a set of relationships to estimate the P-wave velocity and petrophysical properties based on well $\log$ data using the multiple regression analysis techniques.

In addition, a field case (FAUQI oil field, Jeribe formation), located in southeast Iraq, was conducted to correlate the compressional wave velocity with petrophysical properties. 
The most significant difference between this study and previous studies is that the new model to predict (VP) depend on four-parameter (MR), including porosity, density, water saturation, and shear wave velocity but previous study, the relationship between the two variables are the essential parameters to influence P-wave prediction. The conclusion of this study can be summarized in the following points:

1- It presents a more accurate correlation to estimate compressional wave velocity in Jeribe formation Eastern South of Iraq FAUQI oil field using conventional well log data.

2- The analysis revealed that $\mathrm{Vp}$ could be estimated by correlation with Vs. and NPHI and SW Density. Pwave shows a very strong correlation with this parameter, with a coefficient of 0.93 avoiding the dipole substitution; if dipole substitution is not available as the learned in the abovementioned regression, the predictors include $\mathrm{Vp}$, which was developed to improve the accuracy of $\mathrm{Vp}$ prediction in the studied field.

3- Therefore, this model can be applied accurately, given the observed consistency between the results of the model and data. predict carbonate concentration in the reservoir

4- The Comparison of the results of three correlation (Siddharth, Gist, and Pickett) with new model illustrate that the Multiple regression model-new equation (7) is the most accurate model for $\mathrm{Vp}$ prediction it was able to estimate the $\mathrm{Vp}$ for the validation data of Well-27 with an AARE of 0.019 compared with an AARE of more than 0.033 for all available correlations

\section{Nomenclature}

$\begin{array}{ll}\text { Vp: } & \text { compressional wave } \\ \text { Vs.: } & \text { shear wave velocity } \\ \text { UV: } & \text { ultrasonic velocities } \\ \text { SW: } & \text { Water saturation } \\ \text { Wa: } & \text { water absorption } \\ \text { MR: } & \text { Multiple regressions }\end{array}$

\section{References}

[1] R H Tatham, T Scotellaro and G Mavko, "The effect of chemical and physical processes on the acoustic properties of carbonate rocks," Leading Edge 271982, 2008, pp 10-18.

[2] $\underline{\mathrm{R} \text { Wilkens, G Simmons, and L Caruso, "The ratio }}$ $\mathrm{Vp} / \mathrm{Vs}$. as a discriminant of composition for siliceous limestones Geophysics" 49 1850-60, 1984.

[3] K Duffaut and M Landrø, "Vp/Vs. Ratio versus differential stress and rock consolidation-a comparison between rock models and time-lapse AVO data Geophysics" 72 C81-94, 2007.

[4] E Rojas, "Vp-Vs ratio sensitivity to pressure, fluid, and lithology changes in tight gas sandstones First Break" 26 83-86, 2005.
[5] YJ Tawfeeq, JA Al-Sudani, "Digital Rock Samples Porosity Analysis by OTSU Thresholding Technique Using MATLAB," Iraqi Journal of Chemical and Petroleum Engineering, 21 (3), 2020, pp 57-66

[6] M R Wyllie, A R Gregory, and L W Gardner L W, "An experimental investigation of factors affecting elastic wave velocities in porous media Geophysics" 23, 1958, pp 459-93.

[7] D S Raymer, E R Hunt and J S Gardner, "An improved sonic transit time-to-porosity transform," $21^{\text {st }}$ Annual. Meeting of the Society of Professional Well Log. 1980.

[8] F S Anselmetti and G P Eberli, "Pure Appl. Geophys. Controls on sonic velocity in carbonates," 141, 1993, pp 287-323.

[9] Eberli G P, Baechle G T, Anselmetti FS and Incze M L 2003 Factors controlling elastic properties in carbonate sediments and rocks Leading Edge 22 65460 .

[10] T Vanorio, C Scotellaro, and Scotellaro G Scotellaro, "The effect of chemical and physical processes on the acoustic properties of carbonate rocks Leading Edge" 27 1040-8, 2008.

[11] M. Fener, "The effect of rock sample dimension on the P-wave velocity, Journal of Nondestructive Evaluation, 30 (2) (2011), pp. 99-105.

[12] M.Z.A. Duranni, K. Willson, J. Chen, B. Tapp, J. Akram "Rational rock physics for improved velocity prediction and reservoir properties estimation for Granite Wash (Tight Sands) in Anadarko Basin," Texas International Journal of Geophysics (23) (2014), pp. 1-15.

[13] M.N. Toksoz, C.H. Cheng, A. Timur, "Velocity of seismic waves in porous rock," Geophysics, 41 (1976), pp. 621-645.

[14]N Sie, "Experimental Study of water saturation effect on the acoustic velocity of sandstone J. Nat. Gas Sci. Eng., 33 (2016), pp. 37-43.

[15] L Zhang, "Engineering properties of rocks" Butterworth-Heinemann, 2016.

[16] W, Me T, "Evaluation of rock properties using ultrasonic pulse technique and correlating static to dynamic elastic constants." In: 2nd south Asian geoscience conference and exhibition, GEO India 2011, Greater Noida, New Delhi, India.

[17] C Kurtulus, S Cakir, AC Yogurtcuoglu, "Ultrasound study of limestone rock physical and mechanical properties." Soil Mech Found Eng vol 52, No 6, 2016, pp27-31.

[18] Pickett G.R., 1963, Acoustic character logs and Their Application in Formation Evaluation ,J. Pet. Tech. June, 15 No.6.

[19] Gist G A, Thompson A U, Berry "Wave velocities in sandstones from elastic network simulations." Geophysics 58, no. 3 (1993): 334-343.

[20] Karami, M., Dayani, S., Faramarzi, L. "Empirical Correlations between Static and Dynamic Properties of intact rock." In ISRM Regional Symposium-7th Asian Rock Mechanics Symposium. OnePetro, 2012. 
[21]Christensen, N.I., Stanley, D. Seismic velocities and densities of rocks. International Handbook of Earthquake and Engineering Seismology 818, 2003, pp 1587-159.

[22] S Garia. A comprehensive analysis on the relationships between elastic wave velocities and petrophysical properties of sedimentary rocks based on laboratory measurements, 2019.

[23] M Zoveidavianpoor, A Samsuri, and s Shadizadeh,. Prediction of compressional wave velocity by an artificial neural network using somel well logs in a carbonate reservoir. Journal of Geophysics and Engineering, 2013.

[24] Hadi,F.A. and Nygaard,R . Shear wave prediction in carbonate reservoirs can Artificial neural Network outperform regression Analysis, 2018.

[25] Abdul Majeed, R. K., and A.ALhaleem, A. A., An Accurate Estimation of Shear Wave Velocity Using Well Logging Data for Khasib Carbonate Reservoir Amara Oil Field, 2020. 


\title{
تظوير العلاقة الاحصائية بين سرعة الموجة الانضغاطية والخصائص البتروفيزيائية باستخام بيانات تسجيل الابار لتكوين، الجريبي مكمن الاسمري في حقل الفكة الإنهائ
}

\author{
قحطان عدنان عبدالعزيز و حسن عبدالهادي عبد الحسين
}

قسم هندسة النفط، كلية الهندسة، جامعة بغداد، بغداد، العراق

الخلاصة

تعد بيانات الموجة الانضغاطية مفيدة لاستكثاف المكمن، وعمليات الحفر وإنعاث المكمن، وتوظيف التكسير الهيدروليكي، وخطط التطوير لمكمن معين. توجد بعض العلاقات اللاخطية المعقدة أكثر لايجاد سرعة الموجة الانضغاطية وذلك بسبب الطبيعة والسلوك المختلف للمعايير المختلفة. تطور هذه الدراسة العلاقات الإحصائية بين سرعة الموجة الانضغاطية والخواص البتروفيزيائية من بيانات تسجيل الابار لنكوين الجريبي في حقل الفكة النفطي في الجنوب الثرقي من العراق باستخدام طربقة انحدار احصائية متعددة المتغيرات للتنبؤ بسرعة الموجة الانضغاطية من الخواص البتروفيزيائية وبين أي خاصيتين سرعة موجات القص والمسامية والكثافة وتشبع السوائل في ألصخور الكاربونية. وفد استتنت الدراسة وجود ارتباط خطي قوي بين سرعة الموجة الانضغاطية وسرعة الموجة القصية وبين سرعة الموجة الانضغاطية وكثافة الصخور • يمكن استخدام المعادلات الخطية الناتجة لتقدير سرعة الموجة الانضغاطية من سرعة الموجة القصية أحدهما بدلالة الاخرى. أضهرت نتائج تحليل الانحدار المتعدد إلى أن الكثافة، المسامية والتشبع بالماء وسرعة موجة القص نرتبط ارتباطًا وثثيًا بالسرعة للموجةالانضغاطية.

الكلمات الدالة: المسامية، تثبع الماء، الانحدار المتعدد، الموجة الانضغاطية 